\title{
Effects of Serratia marcescens and Prodigiosin Pigment on the Root-Knot Nematode
} Meloidogyne incognita

\author{
Omnia M. Mohamd ${ }^{1}$, Rania A. A. Hussein ${ }^{1}$, Dina S. S. Ibrahim ${ }^{3}$, Mona H. Badawi ${ }^{2}$ and \\ Hussien E. Makboul ${ }^{2}$
}

${ }^{I}$ Central Agricultural Pesticide Laboratory, Agriculture Research Center, Giza, Egypt.

${ }^{2}$ Department of Agricultural Microbiology, Faculty of Agriculture, Cairo University, Egypt.

${ }^{3}$ Plant Pathology Research Institute, Agriculture Research Center, Giza, Egypt.

Received: 09 Jan. 2020 / Accepted 15 Mar. 2020 / Publication date: 15 April 2020

\begin{abstract}
The effect of Serratia marcescens culture and culture filtrate on juvenile mortality of the rootknot nematode Meloidogyne incognita was studied in vitro and in vivo on tomato seedlings. The percent of mortality was proportional to the concentration of culture filtrate and exposure period. Prodigiosin from $S$. marcescens was extracted with actone and ethyl acetate then purified using puriflash column and characterized by TLC, mass spectrometry, FTIR. Prodigiosin was screened for controlling root-knot nematode at juvenile stage. The obtained results revealed that the molecular weight of the pigment was $324.7 \mathrm{~m} / \mathrm{z}$, this confirms that the pigment extracted from $S$. marcescens is prodigiosin. In FTIR analysis red pigment from $S$. marcescens revealed absorption at 3315.3 per $\mathrm{cm}$ $(\mathrm{N}-\mathrm{H})$ and 2941.6 per $\mathrm{cm}$ (aromatic C-H), $1450(\mathrm{C}-\mathrm{H})$ alkenes, 1020, $1141(\mathrm{C}-\mathrm{O}, \mathrm{C}-\mathrm{N})$ carboxylic groups. Bacterial cultures showed better results than the control of nematode alone with a value of $58.5 \%$ for juveniles mortality. The culture filtrate of $S$. marcescens at the four tested concentrations showed nematicidal activities against newly hatched juveniles of $M$. incognita after $72 \mathrm{~h}$ of exposure. The pigment was found effective against juvenile stage of $M$. incognita at low concentrations $\left(\mathrm{EC}_{50}\right.$ value after $72 \mathrm{~h}$ was $31.9 \mathrm{mg} \mathrm{ml}^{-1}$ ). It is proved that the use of microbial secondary metabolites can be effective for nematode control rather than using whole organism.
\end{abstract}

Keywords: Serratia marcescens, prodigiosin, Meloidogyne incognita, secondary metabolites.

\section{Introduction}

The root-knot nematode Meloidogyne incognita is a worm-shaped microscopic animal,that causes negligible injury or constraints in crop production. Present strategies for nematode management depend on cultural practices such as crop rotations, use of resistant varieties and use of nematicides which have several disadvantages such as environmental pollution (Gitanjali and Bora, 2019). A number of bacterial species has been used as biocontrol against Meloidogyne spp. such as Enterobacter (Duponnois et al., 1999), actinomycetes (Yavuzaslanoglu et al., 2011), Pseudomonas (Gitanjali and Bora, 2019) and Serratia marcescens (Suryawanshi, 2014). Microorganisms can inhibit plant parasitic nematodes by producing secondary metabolites, enzymes and toxins. Their modes of action include suppression of nematode reproduction, egg hatching and juvenile or direct killing of nematodes (Suryawanshi, 2014). S. marcescens is a Gram negative bacterium, reported to produce cell associated red-colored pigment called prodigiosin (Carbonell et al., 2000). Prodigiosin produced by $S$. marcescens is a promising drug owing to its characteristics of having antifungal, immunosuppressive and antiproliferative activities. It was screened against the juveniles of plantparasitic nematodes associated with banana and eggplant. Another study has also shown the role of different metabolites synthesized by Pseudomonas sp. in nematode infected plants. This study isolated different metabolites, such as alkaline metalloproteinase, cyclo (L-Pro-L-Ile) and many other volatile organic compounds (VOCs) that shown nematicidal activities (Gao et al., 2016). Also several studies showed the effect of different dilutions of cell-free culture filtrate on Meloidogyne incognita under laboratory and in greenhouse conditions. In laboratory, toxicity effect of filtrate was recorded on second stage juveniles (J2), $100 \%$ mortality was recorded in all treatment above the $75 \%$ concentration (Sharma and Sharma 2017). Many PGPR, such as Pseudomonas and Burkholderia,

Corresponding Author: Omnia M. Mohamd, Central Agricultural Pesticide Laboratory, Agriculture Research Center, Giza, Egypt. E-mail: Omniamostafa645@gmail.com 
have been shown to induce suppressive activities against $M$. incognita by reducing gall formation, controlling nematode reproduction, and hatching and killing juveniles through the release of toxins (Khanna et al., 2019).

\section{Material and Methods}

\section{Bacterial strain}

The bacterial strain (S. marcescens) used in the present study was obtained from Soil, Water and Environment Research Institute, Agricultural Research Center (ARC), Giza, Egypt.

\section{Preparation of $S$. marcescens culture and culture filtrate}

The bacterial strain was inoculated in nutrient broth medium and incubated at $30{ }^{\circ} \mathrm{C}$ on a shaker for $48 \mathrm{hrs}$. The liquid culture was centrifuged at $10000 \mathrm{rpm}$ for $30 \mathrm{~min}$ and the supernatant was passed through a $0.045 \mu \mathrm{m}$ Millipore filter. The culture filtrates were kept at $4{ }^{\circ} \mathrm{C}$ for further use.

\section{Preparation of Meloidogyne incognita juveniles (J2) inocula}

Heavily infected root systems of coleus plants were carefully washed by running tap water. Roots were cut into pieces and egg masses were allowed to hatch using modified Baerman technique (Goodey, 1957). Hatched juveniles were collected daily for a week. Numbers of second stage juveniles were counted for in vivo and in vitro experiments according to the design of each experiment.

\section{Extraction of prodigiosin pigment}

A loopful of Serratia marcescens grown on nutrient agar plate for $24 \mathrm{~h}$ was inoculated into 250 $\mathrm{ml}$ flask containing $50 \mathrm{ml} \mathrm{NB}$ (Giri et al., 2004) and incubated in a shaking incubator at $150 \mathrm{rpm}$ and $28{ }^{\circ} \mathrm{C}$ for $24 \mathrm{~h}$. Then, $10 \mathrm{ml}$ of the culture broth was inoculated in powdered peanut broth $(2 \%$ powdered peanut seeds, NB medium, $\mathrm{pH}$ 7) and incubated in a shaking incubator at $150 \mathrm{rpm}$ and 28 ${ }^{\circ} \mathrm{C}$ for $96 \mathrm{~h}$. Culture broth was centrifuged at $10.000 \mathrm{rpm}$ for 15 minutes and the supernatant was extracted with ethyl acetate. The pigment from the cell pellet was extracted with acetone and the extract was centrifuged at 10.000 for 15 minutes. The white pellet was discarded, extracts were evaporated and the wave length scan was done from 200-700 nm (Srimathi et al., 2017).

\section{Purification of the prodigiosin}

The extracted prodigiosin was applied to thin layer chromatography (TLC) plate for further purification using the mixture of chloroform and methanol (9:1) as a solvent system (Casullo de Araujo et al., 2010).. Then, prodigiosin was separated by puriflash column 30 silica HP $-25.0 \mathrm{~g}$ (22 bar). The dried concentrated sample was dissolved in $5 \mathrm{ml}$ of $\mathrm{n}$-hexane and loaded onto the silica gel column and solvent system comprising of n-hexane and ethyl acetate at a flow rate $15 \mathrm{ml} \mathrm{min}{ }^{-1}$. The eluted red colored fractions were collected and assayed for the presence of prodigiosin. The fractions containing prodigiosin were pooled and concentrated by evaporation at $40{ }^{\circ} \mathrm{C}$ using rotary evaporator.

\section{Characterization of prodigiosin}

Thin-Layer Chromatography (TLC)

Thin layer chromatography (TLC) was performed on silica gel TLC- cards for purification using a mixture of chloroform: methanol $(9: 1)$ as a solvent system.

\section{Mass spectroscopy}

The molecular weight of the prodigiosin was determined using Quick mass determination (Probe / TLC-MS) at Nawah Scientific Research, Cairo, Egypt.

\section{Fourier-Transform Infrared Spectroscopy (FTIR Spectroscopy)}

The purified prodigision sample was subjected to FTIR spectroscopic analysis. FTIR was carried out by mixing the sample with finely grounded $\mathrm{KBr}$. The parameters used in FTIR analysis were; spectral range between 4000 and $400 \mathrm{~cm}^{-1}$. Upon pressing under $2000 \mathrm{kPa}$, pellet disc obtained was analyzed using JASCO FTIR -3600 infrared spectrometer by employing KBr pellet technique, 
equipped with $\mathrm{KBr}$ beam splitter with DTCS (Deuterated triglycine sulfate detector (7800-350 $\mathrm{cm}^{-1}$ ) at the National Center for Radiation Research and Technology (NCRRT), Atomic Energy Authority, Egypt.

\section{Nematicidal effect of bacterial culture and culture filtrate of $S$. marcescens on $M$. incognita juvenile's mortality}

One milliliter of bacterial culture was added to one hundred second stage juveniles $\left(\mathrm{J}_{2}\right)$ of $M$. incognita were separately placed in Petri dishes $(5 \mathrm{~cm}$-dia). Petri dishes receiving distilled water and free of bacterial culture were served as control. Treatments of bacterial culture were replicated three times. Juveniles exhibited no movement and attained the shape of straight line were considered dead. Dead nematodes were counted and recorded after $24 \mathrm{hrs}$. Meanwhile, one milliliter of culture filtrate in four concentrations $\left(200 \times 10^{3}, 400 \times 10^{3}, 800 \times 10^{3}\right.$ and $\left.1000 \times 10^{3} \mu l\right)$ in addition to one hundred second stage juveniles $\left(\mathrm{J}_{2}\right)$ of $M$. incognita were separately placed in Petri dishes. Treatments of each concentration were replicated three times. Dead nematodes were counted and recorded after $72 \mathrm{hrs}$. Percentages of nematode mortality were calculated and recorded for each concentration tested. $\mathrm{EC}_{50}$ was also estimated for each concentration. Concentrations of culture filtrate that gave the highest suppression in nematode population were chosen for in vivo experiment.

\section{Nematicidal effect of prodigiosin pigment on $M$. incognita juvenile's mortality}

Meloidogyne incognita was treated with prodigiosin dissolved in DEMSO at the concentrations $25,50,75,100 \mathrm{mg} \mathrm{ml}^{-1}$ with four wells per treatment in each trial. Juveniles exhibited no movement and attained the shape of straight line were considered dead. Dead nematodes were counted and recorded after $72 \mathrm{hrs}$. Percentages of nematode mortality were calculated and recorded for each concentration tested.

\section{In vivo experiment}

Seedlings of tomato cv. 010 (25-day old) were separately transplanted in plastic pots $(15 \mathrm{~cm}$ dia) filled with $850 \mathrm{~g}$ steam sterilized clay sandy soil (v/ v. 1:1). Simultaneously, culture and culture filtrate of Serratia marcescens were separately applied @ $60 \mathrm{ml} \operatorname{plant}^{-1} \operatorname{pot}^{-1}$. Five days later, seedlings were inoculated with 1000 juveniles of $M$. incognita. The conventional nematicide oxamyl was applied at the recommended dose $\left(0.3 \mathrm{~g} \mathrm{plant}^{-1}\right.$ pot $\left.^{-1}\right)$ two days after nematode inoculation for comparison. Pots free of nematode inoculum were served as CK1, however those received nematode inoculum served as CK2. Each treatment was replicated four times. All pots received water when needed and arranged in a complete block design and kept under greenhouse conditions at $27 \pm 3{ }^{\circ} \mathrm{C}$. Forty two days after nematode inoculation, plants were harvested. Lengths and fresh weights of shoots and roots as well as shoot dry weights for each replicate were recorded. Second stage juveniles of M. incognita were extracted from soil using modified Baermann-technique (Goodey, 1957) and counted. Roots were stained in acid fuschin lactic acid (Byrd et al., 1983), for the numbers of galls, egg masses, females, and development stages. The nematode reproduction (Rf), root gall index (RGI) and egg mass index (EI) were determined as well.

\section{Defense related compounds}

Total phenols (TP) in fresh leaves of tomato were measured according to the method of Javaheri et al. (2012).

\section{Enzymes Activities}

Enzyme extracts were prepared following the method described by Maxwel and Bateman (1967). Fresh leaves $(0.5 \mathrm{~g})$ of each treatment were ground in $3 \mathrm{ml} \mathrm{Na}$-phosphate buffer at $\mathrm{pH} 6.8$ in a mortar then centrifuged at $1500 \mathrm{rpm}$ for $20 \mathrm{~min}$ at $6{ }^{\circ} \mathrm{C}$. The resultant supernatant fluids were processed for enzyme assays.

\section{Peroxidase activity (PO)}

Peroxidase activity was assayed using photochemical method as described by Amako et al. (1994). The reaction mixture was added as the following sequences, $15 \mathrm{ml}$ phosphate buffer, $4.8 \mathrm{ml}$ hydrogen peroxidase, $10 \mathrm{ml}$ pyrogallol and $0.2 \mathrm{ml}$ sample extract. Increasing the absorbance at 430 
$\mathrm{nm}$ was recorded against blank with phosphate buffer instead of enzyme extract. One unit of enzyme activity was defined as the amount of the enzyme, which changing the optical density at $430 \mathrm{~nm}$ per min. at $25{ }^{\circ} \mathrm{C}$ under standard assay conditions. Specific activity was expressed in units by dividing it to $\mathrm{mg}$ protein.

\section{Polyphenol oxidase (PPO)}

Polyphenol oxidase activity was assayed using photochemical method as described by Coseteng and Lee (1987). The reaction mixture was added as the following sequences: $2.7 \mathrm{ml}$ potassium phosphate buffer $90.05 \mathrm{M}, \mathrm{pH} 6.2,0.25 \mathrm{ml}$ of $0.25 \mathrm{M}$ catechol, $0.05 \mathrm{ml}$ of enzyme extract. The increasing in absorbance at $420 \mathrm{~nm}$ was measured. One unit of enzyme activity is defined as the amount of the enzyme that causes an increase of 0.001 absorbance unit per minute at $25^{\circ} \mathrm{C}$.

\section{Statistical analysis}

Data were subjected to analysis of variance (ANOVA) (Gomez and Gomez, 1984), followed by Duncan's multiple range tests to compare means (Duncan, 1955).

\section{Results and Discussion}

\section{Purification of prodigision}

Twenty $\mu \mathrm{l}$ containing $10 \mathrm{mg}$ of the purified pigment were spotted on TLC and separated using chloroform : methanol (9:1) solvent system. A single band with Rf 0.9 was obtained (Fig.1).

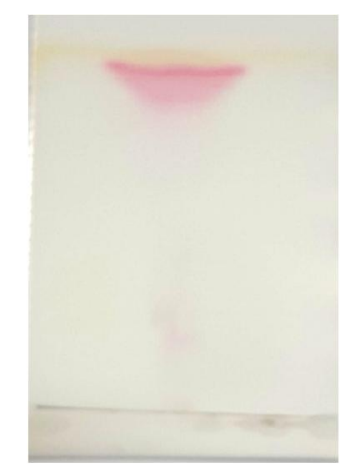

Fig.1: Detection of prodigiosin from S. marcescens on TLC.

\section{Characterization and identification of prodigiosin}

Mass spectroscopy

Characterization of pigment was carried out by TLC mass spectroscopy, the obtained results revealed that the molecular weight of the pigment was $324.7 \mathrm{~m} / \mathrm{z}$ (Fig. 2) This confirms that the pigment extracted from $S$. marcescens is prodigiosin.

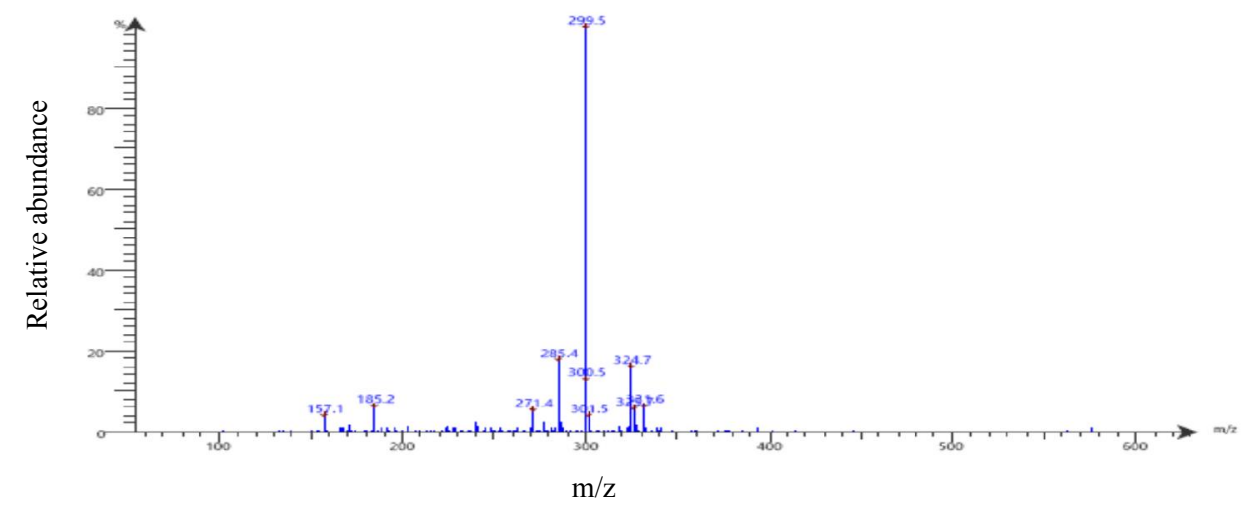

Fig. 2: TLC mass spectroscopy of prodigiosin produced by $S$. marcescens 


\section{Fourier Transform Infrared (FTIR) spectrum of prodigiosin pigment}

In FTIR analysis red pigment from S. marcescens revealed absorption at 3315.3 per $\mathrm{cm}(\mathrm{N}-\mathrm{H})$ and 2941. 6 per cm (aromatic C-H) , $1450(\mathrm{C}-\mathrm{H})$ alkenes, 1020, 1141 (C-O, C-N) carboxylic groups, as represented in (Fig. 3) These results are in accordance with Song et al. (2006).

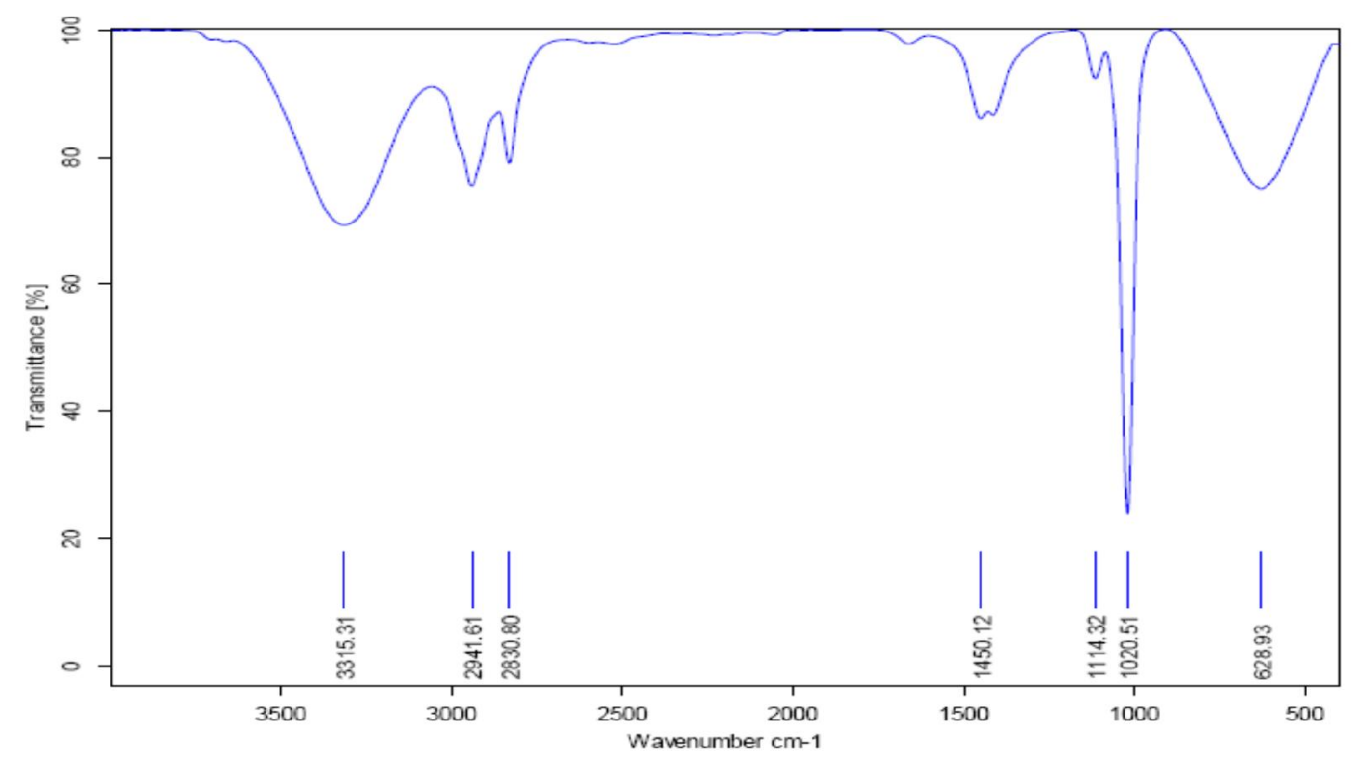

Fig. 3: FTIR analysis for prodigision.

\section{Nematicidal effects of bacterial culture and culture filtrate of $S$. marcescens on juveniles survival of M. incognita}

Data in Table (1) represent the impact of bacterial culture as well as culture filtrate of Serratia marcescens at different concentrations $\left(200 \times 10^{3}, 400 \times 10^{3}, 800 \times 10^{3}\right.$ and $\left.1000 \times 10^{3} \mu 1\right)$ on juveniles mortality of Meloidogyne incognita. Bacterial cultures showed better results than the control of nematode alone with a value of $58.5 \%$ for juveniles mortality. The culture filtrate of $S$. marcescens at the four tested concentrations showed nematicidal activities against newly hatched juveniles of $M$. incognita after $72 \mathrm{~h}$ of exposure. Irrespective of tested concentrations, all treatments were found to cause significant inhibition in juveniles mortality to various extents. However, a positive correlation was achieved among tested concentrations, the higher concentrations the greater juveniles mortality. The highest percentage of $M$. incognita juveniles mortality $(82.0 \%)$ was recorded with the highest concentration of culture filtrate.

Table 1: Nematicidal effect of bacterial culture and culture filtrate of $S$. marcescens on $M$. incognita juveniles mortality

\begin{tabular}{cccc}
\hline Bacterial culture & \multicolumn{3}{c}{ \% of mortality after 24 h } \\
\hline S. marcescens & \multicolumn{2}{c}{0.0} \\
Nematode alone & \multicolumn{3}{c}{ Period of exposure (h) } \\
& $24 \mathrm{~h}$ & $48 \mathrm{~h}$ & $72 \mathrm{~h}$ \\
$\mathbf{2 0 0}$ & 15.0 & 25.0 & 33.0 \\
$\mathbf{4 0 0}$ & 28.0 & 35.0 & 41.0 \\
$\mathbf{8 0 0}$ & 36.0 & 42.0 & 64.0 \\
$\mathbf{1 0 0 0}$ & 45.0 & 56.0 & 82.0 \\
Nematodentration of culture filtrate $(\boldsymbol{\mu l})$ & 0.0 & 0.0 & 3.0 \\
$\mathbf{E C}_{\mathbf{5 0}}$ & 1037 & 892.85 & 421 \\
\hline
\end{tabular}

Moderate results in nematode survival were recorded with other concentrations. These results are in the same line with El-Hadad et al. (2010) who reported that, the filtrates of all bacterial cultures were less effective on nematode mortality compared with whole bacterial cultures. In addition Zaghloul et 
al. (2015) showed that, the bacterial culture of $S$. marcescens at dilutions of $10^{-1}, 10^{-2}$ and $10^{-3}$ recorded the highest values of $M$. incognita mortality being 92.9, 82.9 and $54.3 \%$, respectively. Ketabchi et al. (2016) studied the effect of Serratia sp. on second stage juvenile mortality of $M$. incognita under laboratory conditions after 24,48 and $72 \mathrm{hrs}$ which caused the higher mortality of second stage juvenile. These results are also conformity with the findings of previous reports by Mokbel and Alharbi (2014) who found that S. marcescens showed moderate inhibition of $50.5-62.0$ $\%$ in egg-hatch and $\mathrm{J}_{2}$ activity.

\section{Nematicidal effect of prodigiosin pigment on $M$. incognita juvenile's mortality}

The purified pigment of $S$. marcescens was evaluated as well for nematicidal activity against $M$. incognita in vitro at different concentrations after $72 \mathrm{~h}$ of exposure (Table 2). The pigment exhibited high toxic action against juveniles. The higher the concentrations the greater juveniles mortality. The highest percentage of $M$. incognita juveniles mortality $(84.0 \%)$ was recorded with the highest concentration of $100 \mathrm{mg} \mathrm{ml}^{-1}$. Herein, the least percentage (44.6\%.) of juveniles mortality was recorded with $25 \mathrm{mg} \mathrm{ml}^{-1}$ of purified pigment, with $\mathrm{EC}_{50}=31.9$. Results indicated that the pigment of $S$. marcescens had strong nematicidal candidature compared with synthetic pesticides. These results are in accordance with Rahul et al. (2014). The mode of action of prodigiosin may be due to it possesses proton sequestering ability (Roser et al., 2007) which affects intracellular $\mathrm{pH}$ gradient. Prodigiosin also affects mitochondrial ATP synthesis; it causes reduction in ATP production without decreasing the oxygen consumption.

Table 2: In vitro nematicidal effect of $S$. marcescens pigment on root-knot nematode $M$. incognita juveniles mortality in vitro

\begin{tabular}{|c|c|c|c|}
\hline \multirow[t]{2}{*}{ Concentration $\mathrm{mg} \mathrm{ml}^{-1}$} & \multicolumn{3}{|c|}{$\begin{array}{c}\text { \% of mortality } \\
\text { Period of exposure (h) }\end{array}$} \\
\hline & $24 \mathrm{~h}$ & $48 \mathrm{~h}$ & $72 \mathrm{~h}$ \\
\hline 25 & 25.2 & 33.32 & 44.6 \\
\hline 50 & 31.3 & 48.3 & 62 \\
\hline 75 & 37.3 & 48.6 & 67.3 \\
\hline 100 & 66.6 & 67.2 & 84 \\
\hline EC50 & 85 & 57.8 & 31.9 \\
\hline
\end{tabular}

\section{Impact of bacterial culture and culture filtrate of $S$. marcescens on growth of tomato infected with $M$. incognita}

Data in Table (3) summarize the effect of bacterial culture and culture filtrate of $S$. marcescens on growth of tomato cv. 010 infected with $M$. incognita under greenhouse conditions. Results indicated that $M$. incognita infection caused an obvious reduction in plant growth parameters with reduction percentage in total plant fresh weight and plant length reached 77.3 and $22.3 \%$, respectively.

Table 3: Impact of bacterial culture and culture filtrate of $S$. marcescens on growth of tomato infected with M. incognita

\begin{tabular}{|c|c|c|c|c|c|}
\hline \multirow{2}{*}{ Treatments } & \multicolumn{2}{|c|}{$\begin{array}{l}\text { Length } \\
\text { (cm) }\end{array}$} & \multicolumn{2}{|c|}{$\begin{array}{c}\text { Fresh weight } \\
\text { (g) }\end{array}$} & \multirow{2}{*}{$\begin{array}{c}\text { Shoot } \\
\text { D.W } \\
\text { (g) }\end{array}$} \\
\hline & Shoot & Root & Shoot & Root & \\
\hline S. marcescens culture & $32.6^{\mathrm{a}}$ & $9.5^{\mathrm{a}}$ & $3.65^{b}$ & $0.6^{\mathrm{cd}}$ & $0.0310^{\mathrm{b}}$ \\
\hline S. marcescens culture filtrate & $28^{\mathrm{c}}$ & $8^{b}$ & $3.2^{b}$ & $0.5^{\mathrm{cd}}$ & $0.0293^{\mathrm{d}}$ \\
\hline Oxamyl & $30^{b}$ & $8^{b}$ & $4.5^{\mathrm{a}}$ & $0.8^{\mathrm{ab}}$ & $0.0411^{\mathrm{a}}$ \\
\hline Plant free of $N$ and Untreated & $26^{d}$ & $8.6^{\mathrm{a}-\mathrm{b}}$ & $3.3^{b}$ & $0.83^{\mathrm{a}}$ & $0.0302^{\mathrm{c}}$ \\
\hline Nematode alone & $22.6^{\mathrm{e}}$ & $5.6^{\mathrm{c}}$ & $1.866^{\mathrm{c}}$ & $0.46^{\mathrm{d}}$ & $0.0125^{\mathrm{e}}$ \\
\hline
\end{tabular}

Means in each column followed by the same letter (s) did not differ at $p<0.05$ according to Duncan's multiple range test.

Irrespective of treatments, both application, showed moderate increase in shoot and root lengths and plant biomass exceeded that of untreated plants. Apparently, S. marcescens culture showed better results than $S$. marcescens culture filtrate. The highest significant improvement in tomato plant length 
was recorded with $S$. marcescens culture with percentage increase reached (48.8). On the other hand, the best increase in total plant fresh weight was recorded with $S$. marcescens culture $(82.4 \%)$ followed by $S$. marcescens culture filtrate (58.7\%). Oxamyl as a standard nematicide exceeded other treatments and improved fresh shoot and root weights. Some authors proposed that endophytic bacteria can offer several benefits to the host plant, particularly growth promotion and protection from pathogens; and that under diverse environmental conditions endophytes are able to communicate and interact with the plant more efficiently than rhizospheric bacteria (Ali et al., 2012; Coutinho et al., 2015; Mokbel and Alharbi, 2014; Santoyo et al., 2016).

The nematicidal properties of culture and culture filtrate of $S$. marcescens against $M$. incognita infecting tomato are depicted in Table (4). Both bacterial treatments significantly suppressed nematode population whether in soil or root as compared to control. Culture of $S$. marcescens detected greater suppression in nematode population in soil. Similar trend was noticed with number of developmental stages, females and eggs /egg mass within tomato roots. Oxamyl as conventional nematicide significantly suppressed nematode population in soil and roots with reproduction factor $(\mathrm{Rf})=0.34$ compared to untreated inoculated plants. Root galling was significantly reduced by both treatments of bacterial extracts (Table 5). Bacterial culture treatments significantly suppressed root galling with reduction percentage of $73.5 \%$ and showed better performance in suppressing root galling than culture filtrate. Similar trend was noticed with number of egg masses. Oxamyl (97.1\%) showed significant reduction in root galling with $\mathrm{RGI}=1.0$. These results are in harmony with those of (Mohamed et al. (2009), Abd-Elgawad and Kabeil, (2012), Ketabchi et al., (2016) and Sharaf et al. (2016).

Table 4: Development and reproduction of $M$. incognita as influenced by the addition of bacterial culture and culture filtrate of $S$. marcescens

\begin{tabular}{|c|c|c|c|c|c|}
\hline \multirow[b]{2}{*}{ Treatments } & \multicolumn{3}{|c|}{ Nematode population in } & \multirow{2}{*}{$\begin{array}{c}\text { Total } \\
\text { nematode } \\
\text { population }\end{array}$} & \multirow[b]{2}{*}{ Rf* } \\
\hline & Soil & $\begin{array}{c}\text { Root } \\
\text { Developmental stages }\end{array}$ & Females & & \\
\hline $\begin{array}{l}\text { S. marcescens culture } \\
\text { filtrate }\end{array}$ & $718.0^{b-d}$ & $5.0^{\mathrm{a}}$ & $9.0^{b}$ & 738 & 0.74 \\
\hline
\end{tabular}

Nematode(Pi) $=1000$ juveniles $(\mathrm{J} 2)$ of $\mathrm{M}$. incognita.

Each value is the mean of four replicates.

$\mathrm{Rf}=$ Reproduction factor $=$ Final population $(\mathrm{Pf}) /$ Initial population $(\mathrm{Pi})$

$\mathrm{Pf}=$ Nematode population in soil $+\mathrm{N}$. developmental stages + No. females + No. egg mass

Means in each column followed by the same letter (s) did not differ at $\mathrm{p}<0.05$ according to Duncan multiple range test.

Table 5: Reduction percentages in root galling and number of egg masses of $M$. incognita in tomato plant as influenced by the addition of bacterial culture and culture filtrate of $S$. marcescens

\begin{tabular}{lcccccc} 
Treatments & $\begin{array}{c}\text { No. of } \\
\text { galls }\end{array}$ & $\begin{array}{c}\text { Red. } \\
(\%)\end{array}$ & RGI* $^{*}$ & $\begin{array}{c}\text { No. of egg } \\
\text { masses }\end{array}$ & $\begin{array}{c}\text { Red. } \\
(\%)\end{array}$ & E.I.* $^{*}$ \\
\hline S. marcescens culture & $9.0^{\mathrm{c}}$ & 73.5 & 2.0 & $6.0^{\mathrm{b}}$ & 68.4 & 2.0 \\
S. marcescens culture filtrate & $11.0^{\mathrm{b}}$ & 67.6 & 3.0 & $7.0^{\mathrm{b}}$ & 63.2 & 2.0 \\
Oxamyl & $1.0^{\mathrm{d}}$ & 97.1 & 1.0 & $1.0^{\mathrm{c}}$ & 94.7 & 1.0 \\
Nematode alone & $34.0^{\mathrm{a}}$ & 0.0 & 3.0 & $19.0^{\mathrm{a}}$ & 0.0 & 3.0 \\
\hline
\end{tabular}

Nematode $=1000$ juveniles $\left(\mathrm{J}_{2}\right)$ of $M$. incognita. Each value is the mean of four replicates.

* Root gall index (RGI) or egg-masses index (EI) was determined according to the scale given by Taylor \& Sasser (1978) as follows : $0=$ no galls or egg masses, $1=1-2$ galls or egg masses $; 2=3-10 ; 3=11-30 ; 4=31-100 ;$ and $5=$ more than 100 galls or egg masses.

\section{Biochemical activities}

The influence of bacterial culture and culture filtrate of Serratia marcescens on chemical components viz., total phenol, $\mathrm{PO}$ and PPO activities in leaves of tomato infected with $M$. incognita is presented in Table (6). 


\section{Total phenol}

As a result of root-knot nematode $M$. incognita infection, total phenol increased (48.0\%) in fresh tomato leaves. The highest reduction in total phenol $(17.3 \%)$ was recorded with the conventional nematicide, oxamyl. Among tested bacterial extracts, the highest reduction in total phenol was recorded with $S$. marcescens culture $(15.7 \%)$ than $S$. marcescens culture filtrate $(7.2 \%)$.

\section{Enzyme activities}

As a result of $M$. incognita infection, Po activity obviously raised in tomato leaves with percentage increase of 45.7 . Among tested bacterial extracts, the highest reduction in PO enzyme $(20.7 \%)$ was recorded with $S$. marcescens culture followed by $S$. marcescens culture filtrate $(10 \%)$. Oxamyl exceeded both bacterial treatments giving the highest reduction in PO enzyme $(27 \%)$. Similar trend was noticed with PPO activity. Herein, PPO activity (38.4\%) was also increased in fresh tomato leaves as a result of $M$. incognita infection. However, application of tested bacterial extracts as soil drench showed PPO activity reduction in tomato leaves. Tomato treated with $S$. marcescens culture (19.8\%) exhibited the highest percentage of decrease in PPO activity followed by S. marcescens culture filtrate $(7.9 \%)$. Oxamyl recorded that the highest percentage of decrease $(24.5$ $\%)$ in PPO activity exceeding both bacterial treatments. Some authors showed that nematode infestation induces an increase in the activity of PO and PPO enzymes. In this respect, Abd-Elgawad and Kabeil, (2012) indicted that PPO activity was enhanced in inoculated roots treated with commercial suspension of $S$. marcescens (Nemaless) with respect to uninoculated roots. In tomato roots infected with root-knot nematodes, genes with homology to several known plant defense genes such as peroxidase (PO) and chitinase are induced locally within $12 \mathrm{~h}$ of inoculation (Williamson and Hussey, 1996).

Table 6: Impact of bio-agents on resistance compounds in leaves of tomato infected with Meloidogyne incognita

\begin{tabular}{|c|c|c|c|c|c|c|}
\hline \multirow{2}{*}{ Treatments } & \multicolumn{6}{|c|}{ Chemical parmeters } \\
\hline & PO & Dec $\%$ & PPO & Dec \% & T. phenol mg/1g & Dec $\%$ \\
\hline S. marcescens culture & $0.563^{\mathrm{c}}$ & 20.7 & $0.121^{\mathrm{c}}$ & 19.8 & $4.059^{\mathrm{c}}$ & 15.7 \\
\hline S. marcescens culture filtrate & $0.639^{b}$ & 10 & $0.139^{b}$ & 7.9 & $4.465^{b}$ & 7.2 \\
\hline Oxamyl & $0.518^{\mathrm{d}}$ & 27 & $0.114^{\mathrm{d}}$ & 24.5 & $3.978^{\mathrm{d}}$ & 17.3 \\
\hline Plant free of $N$ and untreated & $0.385^{\mathrm{e}}$ & 45.7 & $0.093^{\mathrm{e}}$ & 38.4 & $3.252^{\mathrm{e}}$ & 32.4 \\
\hline Nematode alone & $0.71^{\text {a }}$ & 0.0 & $0.151^{\mathrm{a}}$ & 0.0 & $4.813^{\mathrm{a}}$ & 0.0 \\
\hline
\end{tabular}

Means in each column followed by the same letter (s) did not differ at $p<0.05$ according to Duncan'smultiple range test.

$\mathrm{PO}=$ peroxidase $\quad \mathrm{PPO}=$ polyphenol oxidase

\section{Conclusion}

The present study proved that the culture and culture filtrate of Serratia marcescens have potentialities for controlling the root-knot nematode Meloidogyne incognita under in vitro and in vivo studies. Also, prodigision pigment extracted from $S$. marcescens was very effective for nematode inhibition, low concentrations of prodigision was found to inhibit the juvenile stage of M. incognita. The $\mathrm{LC}_{50}$ value of prodigision was $31.9 \mathrm{mg} \mathrm{ml}^{-1}$ after $72 \mathrm{~h}$. In order to recommends the nematicidal activity of prodigision, field studies are required.

\section{References}

Abd-Elgawad M.M.M. and S.S.A. Kabeil, 2012. Biological control of Meloidogyne incognita by Trichoderma harzianum and Serratia marcescens and their related enzymatic changes in tomato roots. Afri. J. Biotechnol., 11(96): 16247-16252.

Ali T.C. and B.R. Charles, 2012. Delay of flower senescence by bacterial endophytes expressing 1aminocyclopropane-1-carboxylate deaminases J. Appl. Microbiol., 113(5): 1139-1144.

Amako A., G.X. Ghen and K. Asala, 1994. Separate assays specific for the ascorpate peroxides and guaiacol peroxidase and for the chloroplastic and cytosolic isozyme of ascorbate peroxidase in plants. Plant cell Physiol., 35(3): 497-507. 
Byrd, D.W., T. Kirapatrick and K. Barker, 1983. An improved technique for clearing and staining plant tissues for detection nematodes. J. Nematol., 15(3), 142-143.

Carbonell, T., H.H.M. Della Colleta, T. Yano, A.L.C. Darini, C.E. Levy and B.A.L. Fonseca, 2000. Clinical relevance and virulence factors of pigmented Serratia marcescens. FEMS Immunol Med Microbiol., 28(2): 143-149.

Casullo de Araújo, H.W., K. Fukushima and G.M.C. Takaki, 2010. Prodigiosin production by Serratia marcescens UCP 1549 using renewable-resources as a low cost substrate. Molecules, 15(10): 6931-6940.

Coseteng M.Y. and C.Y. Lee, 1987. Change in apple polyphenol oxidase and polyphenol concentrations in relation to degree of browning. J. Food Sci., 52:985-989.

Coutinho B.G., D. Licastro, M. Mendonca-Previato and V.V. Camara, 2015. Plant-influenced gene expression in the rice endophyte Burkholderia kururiensis M130 Molec. Plant-Microbe Interact., 28(1):10-21.

Duponnoisc, R., A.M. Ba and T. Mateille, 1999. Beneficial effects of Enterobacter cloacae and Pseudomonas mendocina for biocontrol of Meloidogyne incognita with the endospore-forming bacterium Pasteuria penetrans. Nematol., 1(1): 95-101.

Duncan D.B., 1955. Multiple range and multiple, F-test Biometrics, 11(1): 1- 42.

El-Hadad, M.E., M.I. Mustafa, S.M. Selim, A.E.A. Mahgoob, T.S. Abdel A. El-Tayeb, and Norhan H. ,2010. In vitro evaluation of some bacterial isolates as biofertilizers and biocontrol agents against the second stage juveniles of Meloidogyne incognita. World J. Microbiol. Biotechnol., 26(12): 2249-2256.

Giri, A.V., N. Anandkumar, G. Muthukumaran and G. Pennathur, 2004. A novel medium for the enhanced cell growth and production of prodigiosin from Serratia marcescens isolated from soil. BMC Microbiol 4:11. Doi: 10:1186/1471-2180-4-11.

Gitanjali, D. and L.C. Bora, 2019. Effect of some bacterial bioagents against root-knot nematodes (Melodogyne incognita race 2). Int. J. Environ. Agric. Biotechnol., 4(1): 52-58.

Gao, H., G. Qi, R. Yin, H. Zhang, C. Li and X. Zhao, 2016. Bacillus cereus strain S2 shows high nematicidal activity against Meloidogyne incognita by producing sphingosine. Scientific Reports 6:7-13.

Gomez, K.A. and A.A. Gomez, 1984. Statistical Procedures for Agriculture Research. $2^{\text {nd }}$ Ed., June Wiley \& Sons. Inc. New York.

Goodey, J.B., 1957. Laboratory methods for work with plant and soil nematodes. Tech. Bull. No.2 Min. Agric. Fish Ed. London, 47.

Javaheri, M., K. Mashayekhi, A. Dadkhah and F. Zaker Tavallaee, 2012. Effects of salicylic acid on yield and quality characters of tomato fruit (Lycopersicumesculentum Mill.) Int. J. Agric. Crop Sci., 4(16):1184-1187.

Ketabchi, S., H. Charehgani and S. Majzoob, 2016. Impact of rhizosphere antagonistic bacteria and urea fertilizer on root-knot nematode (Meloidogyne incognita) under greenhouse condition. J. Anim. Plant Sci., 26(6): 1780-1786.

Khanna, K., V.L. Jamwal, S.K. Kohli, S.G. Gandhi, P. Ohri, R. Bhardwaj, L. Wijaya, M.N. Alyemeni and P. Ahmad, 2019. Role of plant growth promoting bacteria (PGPR) as biocontrol agents of Meloidogyne incognita through improved plant defense of Lycopersicon esculentum. Plant and Soil., 436:325-345.

Maxwell, D.P. and D.F. Bateman, 1967. Changes in the activity of oxidases in extracts of Rhizoctonia infected bean hypocotyls in relation to lesion maturation. Phytopathol., 57, 123-136.

Mohamed, Z.K., S.A. El-Sayed, T.E.E. Radwan and G.S. Abd El-Wahab, 2009. Potency Evaluation of Serratia marcescens and Pseudomonas fluorescens Biocontrol Agents for Root-knot Nematodes in Egypt. J. Appl. Sci. Res., 4 (1):93-102.

Mokbel, A.A., and A.A. Alharbi, 2014. Suppressive effect of some microbial agents on root-knot nematode, Meloidogyne javanica infected eggplant. AJCS 8(10): 1428-1434.

Rahula, S., P. Chandrashekhara, B. Hemanta, N. Chandrakantb, S. Laxmikanta and P. Satish, 2014. Nematicidal activity of microbial pigment from Serratia marcescens. Natural Product Research, 28(17):1399-1404.

Roser, F., P.T. Ricardo, G.B. Pepita, S.C. Vanessa, G.X. Pol and A. Santiago, 2007. Mechanism of prodigiosin cytotoxicity in human neuroblastoma cell lines. Eur. J. Pharmacol., 572(2):111-119. 
Santoyoa, G., G. Moreno-Hagelsiebb, M.C. Orozco-Mosquedac and B.R. Glickc, 2016. Plant growthpromoting bacterial endophytes. Microbiol. Res., 183, 92-99.

Sharaf, A.M.A., A.M. Kailla, M.S. Attia1 and M.M. Nofal (2016). Induced resistance in tomato plants against root knot nematode using biotic and abiotic inducers. Int. J. Adv. Res. Biol. Sci., 3(11): $31-46$

Sharma, I.P. and A.K. Sharma, 2017. Effective control of root-knot nematode disease with Pseudomonas rhizobacteria filtrate. Rhizosphere., 3:123-125.

Srimathi, R., R. Priya, M. Nirmala and A. Malarivizhi, 2017. Isolation, identification, optimization of prodigiosin produced by Serratia marcescans and it's applications. Int. J. Lat. Engin. Mange. Res., (IJLEMR) 2(9): 11-21.

Song, M.J., J. Bae, D.S. Lee, C.H. Kim, J.S. Kim, S.W. Kim and S.I. Hong, 2006. Purification and characterization of prodigiosin produced by integrated bioreactor from Serratia sp. KH-95. J. Biosci. Bioeng., 101(2): 157-161.

Suryawanshi, R., C. Patil, H. Borase, C. Narkhed, L. Shinde and S. Patil, 2014. Nematicidal activity of microbial pigment from Serratia marcescens. Nat. Product Res., 28(17): 1399-1404.

31. Williamson, V.M. and R.S. Hussey, 1996. Nematode pathogensis and resistance in plants. Plant Cell. 8(10), 735-1745.

Yavuzaslanoglu, E., M. Yamac and JM. Nicol, 2011. Influence of actinomycete isolates on cereal cyst nematode heterodera filipjevi juvenile motility. Nematol. Mediterr., 39(1): 41- 45.

Zaghloul, R.A., N.A.Neweigy, H.E. Abou-Aly, S.A. El-Sayed and A.M. Bahloul, 2015. Nematicidal activity of some biocontrol agents against root-knot nematodes in-vitro. RJPBCS., 6(1), 429438. 